\begin{tabular}{c} 
Jurnal Ilmu Pemerintahan, Administrasi Publik, Ilmu Komunikasi (JIPIKOM), 2(2) 2020: 95-103, \\
DOI: \\
Jurnal IImu Pemerintahan, Administrasi Publik, IImu Komunikasi \\
(JIPIKOM) \\
Available online http://jurnalmahasiswa.uma.ac.id/index.php/iipikom \\
Diterima: 11 Agustus 2020; Disetujui: 11 September 2020; Dipublish: 11 Oktober 2020 \\
\hline
\end{tabular}

\title{
Culture Shock dalam Interaksi Komunikasi Antar Budaya pada Mahasiswa Asal Papua di Universitas Negeri Medan
}

\section{Culture Shock In Intercultural Communication Interactions Among Papuan Students at University of Negeri Medan}

\author{
Iyen Herini Situmorang1)*, Effiati Juliana Hasibuan2), Agung Suharyanto3) \\ Program Studi Ilmu Administrasi Publik, Fakultas Ilmu Sosial Dan Ilmu Politik, Universitas \\ Medan Area, Indonesia
}

\begin{abstract}
Abstrak
Penelitian ini berjudul Culture Shock dalam Interaksi Komunikasi Antarbudaya pada Mahasiswa Asal Papua di UNIMED. Metode penelitian yang di pakai adalah penelitian kualitatif yang bersifat deskriptif, dilakukan untuk mendapatkan temuan-temuan di lapangan secara langsung guna menjawab tujuan penelitian.Subjek penelitian ini adalah mahasiswa Papua yang kuliah di UNIMED. Hasil penelitian menunjukkan bahwa para mahasiswa asal Papua memiliki kecenderungan culture shock. Akantetapi mereka sudah hampir bisa menyesuaikan diri dan merasa nyaman tinggal di lingkungan. Fakultas dan motivasi diri ikut mempengaruhi proses komunikasi yang terjalin antara mahasiswa Papua dan mahasiswa UNIMED lainnya. Mahasiswa asal Papua tidak selalu berteman dengan sesamanya tetapi mereka juga berbaur dengan mahasiswa lainnya agar dapat menyesuaikan diri dengan lingkungan barunya dan merasa nyaman kuliah di UNIMED .
\end{abstract}

Kata Kunci: Komunikasi Antar budaya, Culture Shock, Papua.

\begin{abstract}
This study is entitled Culture Shock in Inter-Cultural Communication Interactions for Students from Papua at UNIMED. The research method used was descriptive qualitative research, carried out to obtain findings in the field directly to answer the research objectives. The subject of this study were Papuan students studying at UNIMED. The results showed that students from Papua had a culture shock tendency. But they are almost able to adjust and feel comfortable living in the environment. Faculty and self-motivation also influence the communication process that exists between Papuan students and other UNIMED students. Students from Papua are not always friends with each other but they also mingle with other students so they can adjust to their new environment and feel comfortable studying at UNIMED.
\end{abstract}

Keywords: Intercultural Communication, Culture Shock, Papua.

How to Cite: Situmorang, I.H. Hasibuan, E.J. \& Agung Suharyanto, P. (2020). Culture Shock dalam Interaksi Komunikasi Antar Budaya pada Mahasiswa Asal Papua di Universitas Negeri Medan. Jurnal Ilmu Pemerintahan, Administrasi Publik, Ilmu Komunikasi (JIPIKOM), 2(2) 2020: 95-103, 
Iyen Herini Situmorang, Effiati Juliana Hasibuan \& Agung Suharyanto, Culture Shock dalam Interaksi Komunikasi Antar Budaya pada Mahasiswa Asal Papua di Universitas Negeri Medan

\section{PENDAHULUAN}

Komunikasi antar budaya terjadi, dimana orang-orang yang memiliki budaya berbeda, bisa membentuk suatu kelompok. Didalam kelompok tersebut, mereka berinteraksi antar satu dengan yang lain. Komunikasi merupakan hal yang terpenting dalam kehidupan manusia sebagai makhluk sosial, manusia akan selalu berkeinginan untuk berbicara, tukar-menukar gagasan, mengirim dan menerima informasi berbagai pengalaman, bekerja sama dengan orang lain untuk memenuhi kebutuhan dan sebagainya (Astuti, 2000). Komunikator dan komunikan yang berasal dari budaya yang berbeda akan dapat mencapai komunikasi yang efektif apabila keduanya saling memahami dan menghargai kebudayaan satu sama lain. Jika hal ini tercapai maka akan lahirlah sebuah persahabatan, kesetiakawanan, hingga mengurangi ketidak pastian dan konflik antar budaya (Maulidia, 2012). Maka tidak heran juga potensi terjadinya kekagetan budaya diantara para individu perantau yang tinggal di suatu daerah baru juga akan semakin besar. Pada tahap awal kehidupannya di tempat rantauan ia akan mengalami problem ketidaknyamanan terhadap lingkungan barunya yang kemudian akan berpengaruh baik secara fisik maupun emosional sebagai reaksi ketika berpindah dan hidup dengan lingkungan yang baru terutama yang memiliki kondisi budaya yang berbeda.

Segala bentuk lambang-lambang verbal dan non verbal dan aturan-aturan atau kelompok yang memasuki budaya baru akan mengalami proses enkulturasi yang kedua, yang disebut dengan proses akulturasi. Akulturasi merupakan suatu nilai masuk ke dalam diri individu tanpa meninggalkan identitas budaya yang lama. Salah satu kecemasan yang terbesar adalah mengenai bagaimana harus berkomunikasi, ketika individu masuk dan mengalami kontak budaya lain serta merasakan ketidaknyamanan psikis dan fisik karena kontak tersebut, maka keadaan ini disebut sebagai geger budaya atau culture shock. Culture Shock dapat terjadi ketika seseorang yang meninggalkan kampung halamannya dan berinteraksi dengan lingkungan baru yang ia datang ke lingkungan itu untuk mengejar cita atau pendidikan.

Mahasiswa asal Papua yang kuliah di Universitas Negeri Medan (UNIMED) adalah salah satu contoh yang memasuki lingkungan baru dengan budaya yang berbeda. Mahasiswa itu adalah putra/putri terbaik Papua yang mendapatkan Beasiswa dari pemerintah. Mahasiswa asal Papua akan menghadapi banyak hal yang berbeda seperti cara berpakaian, bertingkah laku, cara berbicara, cuaca, makanan, bahasa, dan nilainilai yang berbeda. Hal ini menjadi penting untuk dipelajari oleh mahasiswa asal Papua untuk mencapai komunikasi yang efektif dengan mahasiswa UNIMED yang berbeda etnik. Untuk menuju suatu adaptasi yang baik dan komunikasi yang efektif maka harus dapat mengatasi culture shock. "Banyak hal yang mempengaruhi proses penyesuaian diri, seperti variable-variabel komunikasi dalam akulturasi. Yakni faktor personal (intrapersonal), seperti karakteristik personal, motivasi individu, Persepsi individu, pengetahuan individu dan pengalaman sebelumnya." (Maulidia, 2012).

Komunikasi menjadi bagian yang sangat penting dalam kehidupan manusia terutama dalam kehidupan sosial. Alasan itulah yang menyebabkan manusia tidak dapat menghindari komunikasi dalam kehidupannya. Menurut Lasswell, komunikasi adalah sebuah proses penyampaian pesan yang dilakukan melalui media kepada komunikan yang menimbulkan efek tertentu.Model komunikasi menurut Lasswell dalam Littlejohn (2011:334) "menggambarkan kajian proses komunikasi secara ilmiah yang menitik beratkan pada berbagai turunan dari setiap elemen komunikasi dan sekaligus 
merupakan jawaban dari pertanyaan yang telah ia kemukakan." Kelima elemen komunikasi tersebut adalah who (siapa), says what (mengatakan apa), in which channel (dengan saluran apa), to whom (kepada siapa), whit what effect (dengan efek bagaimana).

Bentuk Komunikasi dapat diklasifikasikan menurut (suranto, 2010) dalam proses komunikasi, meliputi: komunikasi intrapersonal, komunikasi anatpersonal, komunikasi kelompok, komunikasi massa. Faktor yang menghambat efektitifitas komunikasi menurut (Suranto, 2010), adalah Kredibilitas komunikator rendah, Kurang memahami latar belakang sosial dan budaya, Kurang memahami karakteristik komunikan, Komunikasi satu arah, Perbedaan bahasa. Proses komunikasi antara budaya merupakan interaksi antar pribadi dan komunikasi antar pribadi yang dilakukan oleh beberapa orang yang memiliki latar belakang kebudayaan yang berbeda (Liliweri, 2003). Adapun definisi yang ada mengenai komikasi antar budaya menyakatan bahwa komunikasi antar budaya terjadi apabila terdapat 2 (dua) budaya yang berbeda dan kedua budaya tersebut sedang melaksanakan proes komunikasi.

Hambatan komunikasi atau yang juga dikenal sebagai communication barrier adalah segala sesuatu yang menjadi penghalang untuk terjadinya komunikasi yang efektif. Jenis - jenis hambatan komunikasi antar budaya, yaitu sebagai berikut: fisik (physical), budaya (culture), persepsi (perceptual), motivasi (motivational), pengalaman (Experiantial), emosi (emotional), bahasa (linguistic), nonverbal Channey \& Martin dalam (Sanjaya, 2013 Sanjaya, 2013; Muda, I., 2015; Simanjuntak, R.D., 2016; Hasibuan, E.J, \& Indra M, 2017;). Menurut Suranto dalam (Marselin, 2016) prinsip-prinsip umum untuk memperbaiki kemampuan berkomunikasi dengan berbagai pihak yang berbeda latar belakang, yaitu: Komunikasi hendak meraih tujuan tertentu, Komunikasi adalah suatu proses, komunikasi adalah suatu sistem transaksional informasi, Karakteristik komunikan penting untuk diperhatikan.

Papua adalah sebuah provinsi yang terletak di paling timur Indonesia. Provinsi ini merupakan provinsi yang masih kental dan kaya akan kesenian dan kebudayaan yang ada di provinsi tersebut. Terdapat ratusan bahasa daerah yang berkembang pada kelompok etnik yang ada di Papua. Aneka Berbagai bahasa ini menyebabkan kesulitan dalam berkomunikasi antara satu kelompok etnik dengan kelompok etnik lainya. Oleh sebab itu, Bahasa Indonesia digunakan secara resmi oleh masyarakat. Pakaian adat Papua untuk pria dan wanita hampir sama bentuknya. Pakaian adat itu memakai hiasanhiasan seperti hiasan kepala berupa bentuk burung cendrawasih, gelang, kalung, dan ikat pinggang dari manik-manik, serta rumbai- rumbai pada pergelangan. Rumah Honai terbuat dari kayu dengan atap berbentuk kerucut yang terbuat dari jerami. Honai sengaja dibangun sempit atau kecil dan tidak berjendela yang bertujuan untuk menahan hawa dingin pegunungan Papua.

Istilah "culture shock" pertama kali diperkenalkan oleh Oberg dalam (Dayaksini, 2004) untuk menggambarkan respon yang mendalam dan negative dari depresi, frustasi dan disorientasi yang dialami oleh orang-orang yang hidup dalam suatu lingkungan budaya yang baru. Menurut Edward dalam Hayqal (2011: 55) mendeskripsikan "culture Shock adalah gangguan ketika segala hal yang biasa dihadapi ketika ditempat asal menjadi sama sekali berbeda dengan hal-hal yang dihadapi di tempat yang baru dan asing." Menurut Adler dalam Abbasian,(2013) mengemukakan bahwa "culture shock merupakan reaksi emosional terhadap perbedaan budaya yang tak terduga dan kesalah pahaman pengalama yang berbeda sehingga dapat menyebabkan perasaan 
tidak berdaya, mudah marah, dan ketakutan akan ditipu, dilukai ataupun diacuhkan." (Abbasian, 2013).

Gegar budaya atau culture shock adalah suatu penyakit yang berhubungan dengan pekerjaan atau jabatan yang diderita orang-orang yang secara tiba-tiba berpindah atau dipindahkan ke lingkungan yang baru. Gegar budaya di timbulkan oleh kecemasan yang disebabkan oleh kehilangan tanda-tanda dan lambang- lambang dalam pergaulan sosial. Culture shock didefenisikan sebagai kegelisahan yang mengendap yang muncul dari kehilangan semua lambang dan symbol yang familiar dalam hubungan sosial, termasuk di dalam seribu satu cara yang mengarahkan kita dalam situasi keseharian. Menurut Fumham dan Bochner (2003) faktor-faktor yang mempengaruhi individu mengalamiculture shock saat berinteraksi dengan budaya baru adalah sebagai berikut: Adanya perbedaan budaya kualitas, kuantitas, dan lamanya cultur shock yang dialami individu yang di pengaruhi oleh tingkat perbedaan budaya antara lingkungan dan lingkungan baru individu, Adanya perbedaan individu berkaitan dengan perbedaan dalam ke pribadian dan kemampuan individu menyesuaikan diri di lingkungan barunya, Pengalaman lintas budaya individu sebelumnya (Funham, 2003).

Ada beberapa gejala Culture Shock yang di alami oleh individu yang berada di lingkungan baru Menurut Guanipa dalam (Nian, 2009), diantaranya ialah: Kesedihan, kesepian, dan kelengangan, Preokupasi, Kesulitan untuk tidur, tidur terlalu banyak atau terlalu sedikit, Perubahan perilaku, tekanan, dan depresi, Kemarahan, Mengidentifikasikan dengan budaya lama atau mengidealkan daerah lama, Tidak percaya diri, Rindu keluarga. Namun ada beberapa hal yang biasanya ditunjukkan individu saat mengalami culture shock, yaitu antara lain: Perasaan sedih, kesepian, Menjadi lebih khawatir tentang kesehatan, Menderita rasa sakit diberbagai areal tubuh, Adanya perubahan tempramen, Perasaan marah, mudah tersinggung, penyesalan, tidak bersedia untuk berinteraksi dengan orang lain., Selalu membanding-bandingkan kultur asalnya, Kehilangan identitas, Mencoba terlalu keras untuk menyerap segala sesuatu yang ada di lingkungan barunya. Menurut Amalia (2017) ada beberapa tahapan culture shock yaitu: the honeymoon phase, yaitu suatu tahapan dimana kamu akan merasa bahagia setibanya di Negara yang baru, the crisis phase, yaitu perbedaan di Negara baru tidak pas, baik itu makanannya, logat yang susah dimengerti, kebiasaan jual beli, dan merasa kesepian, the adjustment phase, yaitu dalam fase ini, kamu sudah mulai bisa berinteraksi dengan lingkungan di Negara baru, bicultural phase, yaitu kamu merasa nyaman hidup dengan dua kebudayaan sekaligus (Amalia, 2017).

\section{METODE PENELITIAN}

Metode penelitian pada penelitian ini merupakan metode penelitian kualitatif dengan jenis pendekatan bersifat deskriptif. Melalui penelitian kualitatif, peneliti dapat mengetahui hambatan-hambatan komunikasi antar budaya dan tahaptahapan culture shock yang dialami Mahasiswa asal Papua di UNIMED dalam interaksi Komunikasi Antarbudaya dalam menyesuaikan lingkungan baru. Karakterisitk informan dalam penelitian ini adalah mahasiswa asal papua yang kuliah di Universitas Negeri Medan. Lokasi penelitian yang akan dilakukan adalah Universitas Negeri Medan. Teknik pengumpulan data dalam penelitian disesuaikan dengan masalah, tujuan penelitian, penelitian ini menggunakan teknik pengumpulan dan melalui wawancara dan observasi. 


\section{HASIL DAN PEMBAHASAN}

Hambatan komunikasi fisik semacam ini berasal dari hambatan waktu, lingkungan, kebutuhan diri, dan juga media fisik. Hambatan komunikasi ketika di dalam sebuah lingkungan memiliki berbeda-beda budaya komunikasinya akan sangat kurang efektif karena antara budaya yang satu dengan yang lain memiliki perbedaan-perbedaan yang sulit untuk disatukan, seperti bahasa, cara berpakaian, makanan, dan lainnya. Setelah melakukan penelitian dari lima informan, peneliti mendapatkan hasil bahwasanya empat informan tidak pernah sakit akibat makanan yang ada di Medan, karena mereka berpendapat bahwasanya makanan yang ada di Medan hampir sama dengan yang ada di Papua, tetapi Siska mengatakan"Saya Pernah sakit karena makanan, memang hanya sakit perut biasa saja, tapi memang awal pertama datang ke Medan saya kurang suka dengan makananya, tapi sekarang itu semua sudah baik-baik saja".

Hambatan budaya berasal dari suku yang berbeda mengakibatkan ke-5 informan cukup bingung karena di Medan banyak pendatang, baik dari luar daerah maupun dalam daerah, dan mereka memiliki bahasa yang berbeda-beda oleh karena itu mereka cukup sulit untuk berinteraksi dan cukup sulit untuk mengerti tentang bahasa yang di gunakan mahasiswa lainnya. Yang kedua adalah sosial. Ke-5 informan cukup susah untuk bergaul pertama kali dengan mahasiswa lainnya dan juga perbedaan sosial yang ada antara budaya yang satu dengan yang lainnya yang menyebabkan komunikasi antar budaya kurang efektif sehingga mereka lebih sering berkumpul dengan sesama mereka saja karena menurut mereka itu lebih nyaman daripada berinteraksi dengan orang-orang yang budayanya berbeda. Ke 5 informan pada saat ini masih mencoba menyesuaikan diri dengan lingkungan dan budaya orang Medan, karena kebanyakan orang Medan itu suaranya sangat keras-keras dan orang Medan itu banyak yang angkuh sehingga mereka kurang nyaman.

Jenis hambatan yang merupakan persepsi ini muncul dikarenakan setiap orang memiliki persepsi yang berbeda-beda mengenai suatu hal, sehingga untuk mengartikan sesuatu setiap budaya akan mempunyai pemikiran yang berbeda- beda dan cara hidup yang berbeda-beda pula. Persepsi informan tentang orang Medan sebelum kuliah, menurut Niel, Ferdi, dan Floren tidak tahu sama sekali orang Medan bagaimana, baru tahu dengan kota Medan. tetapi kalau Simson dan Siska, mereka tahu bahwa kota Medan itu ada, dan menurut siska: "kalau orang Medan suara besar hati baik, kalau orang Papua suara besar sedikit tetapi hati keras seperti baja,dan kami orang Papua yang kuliah di sini paling tidak suka di buly dengan mengatakan, sumber air su dekat, karena di kampung kami air lebih bersih dari pada di Medan ini, dan lebih banyak".

Experiental adalah jenis hambatan yang terjadi karena setiap individu tidak memiliki pengalaman hidup yang sama, sehingga setiap individu memiliki presepsi dan juga konsep yang berbeda-beda dalam melihat sesuatu. ke- 5 informan memang membenarkan bahwasanya mereka baru kali ini ke Medan, berbeda dengan Simson dan Floren sudah pernah sebelumnya tinggal di Bandung. Dan sewaktu pertama kali Ferdi 
datang ke Medan, Ferdi mengatakan "saya merasa takut karena saya belum tau bagaimana lingkungan yang ada di Medan itu, dan saya juga tidak mempunyai saudara di Medan, kecuali teman-teman Asrama yang ada di Kampus". Dan kebanyakan dari informan tidak tahu tempat-tempat yang ada di Medan, karena mereka jarang sekali keluar dari Asrama.

Emosi atau perasaan pribadi dari pendengar, apabila emosi pendengar sedang buruk, maka hambatan komunikasi yang terjadi akan semakin besar dan sulit untuk dilalui. Jika seorang sedang emosi, kecil kemungkinan bisa berkomunikasi secara efektif dengan individu tersebut. Konflik dalam masa perkuliahan memang kerap terjadi, tetapi bagi mereka konflik tidaklah harus diperpanjang, karena mereka sadar bahwasanya bukan lagi di kampung mereka sendiri tetapi di kampung orang, kalau ada konflik mereka mengatasinya denga berdiam diri saja, tanpa ada perlawanan. Tetapi kalau konflik mereka jarang mendapatkan hal tersebut, karena yang sangat terkendala pada mereka adalah tugas yang diberikan oleh Dosen.

Bahasa, menjadi hambatan komunikasi terjadi apabila pengirim pesan dan penerima pesan menggunakan bahasa yang berbeda atau penggunaan kata-kata yang tidak dimengerti oleh penerima pesan maka feedback dari pesan tersebut pasti tidak akan sampai dan komunikasinya tidak efektif. Waktu pertama masuk kuliah, pernah mengalami kendala bahasa, akibatnya mereka hanya terdiam saja diruangan, logat mereka yang membuat teman-teman satu ruangannya kurang mengerti dengan apa yang di katakan oleh mereka, karena baru pertama kali datang ke Medan dan terbawa logat Papua dan akhirnya salah paham komunuikasi.

Hambatan nonverbal adalah hambatan komunikasi yang tidak berbentuk katakata, Setelah informan sudah mulai bisa berinteraksi dengan teman kampus, mereka mulai tahu sifat orang Medan itu bagaimana, dan sifatnya juga lama-lama bisa berubah, seperti bahasa, sudah mulai bisa berbahasa Indonesia dengan benar, tanpa mencampur dengan logat Papua. Tingkah laku, dulu mempunyai sifat egois, tetapi setelah berteman dengan orang Medan keegoisan itu lama-lama bisa di ubah menjadi lebih baik lagi. Dan saat sekarang ini mereka tidak lagi memiliki jarak dengan teman satu ruangannya, tetapi untuk di katakan akrab, mereka belum terlalu akrab dengan semuanya, hanya orang-orang tertentu saja.

Motivasi, hambatan semacam ini berkaitan dengan tingkat motivasi dari pendengar, maksudnya adalah apakah pendengar yang menerima pesan ingin menerima pesan tersebut atau apakah pendengar tersebut sedang malas dan tidak punya motivasi sehingga dapat menjadi hambatan komunikasi. Informan tidak pernah merasakan tertekan, tetapi mereka pernah merasakan sakit. Penyebab sakit adalah, rindu keluarga, tugas yang sangat banyak, makan yang kurang, susah tidur, dan lainnya. Pertama kali datang ke Medan mereka sangat susah untuk mendapatkan teman, dan sangat susah untuk bergaul, oleh karena itu lebih sering diam di dalam ruangan. Hanya bergaul denga teman-teman Asrama yang sama-sama berasal dari Papua, karena lebih nyaman 
berteman dengan sesama, karena bisa saling bertukar pikiran, dan bahasanya juga bisa saling memahami satu dengan yang lain.

Tahapan Culture Shock yang ialami mahasiswa Papua adalah Fase optimistik adalah fase pertama yang digambarkan berisi kegembiraan rasa penuh harap tentang sebuah lingkungan yang baru ingin didatangi.Ada fase yang terjadi di lingkungan budaya baru ataupun di lingkungan budaya yang lama. Menurut Ferdi, Siska, dan Niel senang untuk mendatangi suatu Kota yang baru, sebelum mereka belum pernah datangi. Tetapi di balik itu, mereka juga merasa sedih karena akan berpisah dengan kedua orangtuanya dan kelurganya yang lain. Berbeda dengan Simson dan Florida, karena sebelumnya pernah tinggal di kota lain, jadi mereka merasa senang karena akan bertemu dengan orang baru lagi.

Setelah itu fase Masalah kultural adalah dimana masalah dengan lingkungan baru mulai berkembang, misalnya karena kesulitan bahasa, sistem lalu lintas baru, sekolah baru, dan lain-lain. Fase ini biasanya ditandai dengan rasa kecewa dan ketidak puasan, ini adalah periode krisis dalam culture shock. Orang menjadi bingung dan tercengang dengan sekitarnya, dan dapat menjadi frustasi dan mudah tersinggung. Kelima informan memang mengalami rasa kecewa yang sangat besar, karena mereka sangat kesulitan untuk berinteraksi waktu pertama kali datang ke Medan. Dimulai dari logat yang sangat berbeda, dan lalu lintas yang ada di Medan, Seperti Niel, Ferdi, dan Siska memang sama sekali tidak pernah mendapati lalu lintas Seperti yang di Medan ini, karena dari kecil mereka selalu hidup diantara pepohonan dan tanah saja, jarang mereka temui banyak kendaraan seperti di Medan. Pada saat datang ke Medan mereka mulai mempunyai gangguan-gangguan, seperti sulit tidur, tempat yang kurang nyaman, dan sangat rindu keluarga. Ke-5 informan juga memiliki sifat tidak percaya diri sewaktu pertama kali mulai perkuliahan, mereka merasa takut salah mengucapkan katakata dan malu apabila teman-temannya akan menertawakannya. Oleh karena itu, mereka lebih banyak berdiam diri di tempat dudu mereka.

Fase recovery adalah dimana orang mulai mengerti mengenai budaya barunya. Pada tahap ini, orang secara bertahap membuat penyesuaian dan perubahan dalam caranya menanggulangi budaya baru, dan orang-orang, peristiwa dalam lingkungan baru mulai dapat terprediksi dan tidak terlalu menekan.Di fase ini mereka masih belum terbiasa dengan lingkungan yang ada di Medan, mereka masih mencoba menyesuaikan diri sampai sekarang. Sifat orang Medan mereka sudah banyak tahu dan untuk makanan dan bahasa orang Medan mereka juga sudah mulai bisa menyesuaikan, tetapi kalau untuk bahasanya, mereka masih terbawa logat dari Papua, jadi susah untuk dihilangkan. Tetapi walaupun ke-5 informan sudah mulai bisa berinteraksi, tetapi tidak bisa sepenuhnya berinteraksi dengan lingkungan dan orang-orang yang ada di Medan ini

Fase penyesuaian adalah telah mengetahui elemen kunci dari budaya barunya, nilai-nilai, adat khusus, pola komunikasi, dan lain-lain. Kemampuan untuk hidup dalam 2 budaya yang berbeda, biasanya disertai dengan rasa puas dan menikmati. dalam tahap ini sesorang telah berhasil menyesuaikan diri terhadap budaya baru. 
Segala rutinitas masyarakat budaya baru menjadi suatu yang wajar dan biasa. Masalah benturan budaya atau culture Shock sudah berkurang dan reaksi negatif terhadap budaya baru berubah menjadi reaksi positif. Pada tahapan ini, seseorang menyesuaikan diri terhadap budaya baru dengan berbagai cara, antara lain dengan menhindari budaya baru, meninggalkan budaya lama, atau dengan menerima budaya baru yang sesuai dengan nilai-nilai budaya lama. Fase penyesuaian berkisar antara 6 bulan sampai dengan 1 tahun, tergantung dari kondisi fisik dan psikologis seseorang. Untuk sekarang atau sampai sekarang mereka belum bisa sepenuhnya menyesuaikan diri dengan lingkungan Medan masih dalam proses tetapi Niel sudah bisa berinteraksi dengan lingkungan Medan sekitar 1 tahun, Ferdi, 1 tahun, Simson, 3 bulan, Siska 6 bulan, dan Florida 3 bulan, cukup lama mereka bisa berinteraksi dengan teman kampusnya, bisa sampai berbulan-bulan bahkan tahun.

\section{SIMPULAN}

Para mahasiswa asal Papua mengalami culture shock. Hal ini bisa dilihat dari Kebanyakan informan melalui ke-4 fase/ tahapan dalam culture shock, yakni fase optimistic, fase masalah cultural, fase recovery, dan fase penyesuaian. Rata-rata reaksi terhadap culture shock yang di alami adalah rindu kepada lingkungan rumah di Papua (home sick), kurang nyaman dengan orang- orang yang ada di sekitar, karena perbedaan budaya. berarti mereka sudah bisa menyesuaikan diri, namun untuk beberapa informan masih mengalami beberapa masalah adaptasi seperti merasa di perlakukan berbeda dengan penduduk lokal, tidak menguasai bahasa Indonesia dengan baik, dan masih kurang nyaman dengan perbedaan budaya yang ada.

Pada penelitian ini informan memiliki hambatan untuk berkomunikasi dengan masyarakat lokal, yaitu, bahasa yang susah dimengerti informan. Perbedaan budaya membuat mahasiswa lokal sering membuly informan dan mengakibatkan lebih nyaman bersama sesama sukunya daripada mahasiswa lokal. Culture shock yang dirasakan dalam hal interaksi komunikkasi antarbudaya ialah terhadap kuat dan kasarnya cara orang Medan berbicara, karakteristik orang Medan dan juga beberapa perbedaan nilainilai. Dari seluruh perbedaan, bahasalah yang di anggap menjadi persoalan dalam komunikasi.

\section{DAFTAR PUSTAKA}

Abbasian. (2013). The Relationship Between Culture Shock and Socio Linguistic Shock: A Case Non Persia Speaking Lewner. Jurnal of Socio Science Reaserch, 154-159.

Amalia, W. (2017). Mengantisipasi culture Shock. Bandung: PT.Bumi Angkasa.

Astuti. (2000). Revitalisasi Ilmu Komunikasi Melalui Riset. 1-2.

Dayaksini, T. (2004). Psikologi Lintas Budaya. Malang. UMM Culture Shock di Universitas Muhammadiyah Surakarta. Indigenous, jurnal ilmiah Berskala Psikologi, 77-80.

Funham, B. \&. (2003). Culture Shock: Psychological Reaction to Unfamiliar Environment. Methuen \& Co.Ltd.

Hasibuan, E.J, \& Indra M, (2017) Komunikasi Antar Budaya pada Etnis Gayo dengan Etnis Jawa, Jurnal Simbolika: Research and Learning in Comunication Study, 3 (2): 106-113

Liliweri, A. (2003). Dasar- Dasar Komunikasi Antar Budaya. Yogyakarta: Pustaka Belajar.

Marselin. (2016). Komunikasi Antar Budaya di Kalangan Mahasiswa Etnik Manado di Universitas Samratulangi. 5:3-4. 
Maulidia, I. (2012). Culture Shock Dalam Interaksi Komunikasi Antar Budaya Mahasiswa Papui di Universitas Sumatera Utara. Skripsi USU.

Muda, I., (2015), Komunikasi Lintas Etnis di Pulau Weh-Sabang, Jurnal Simbolika: Research and Learning in Comunication Study, 1 (2): 158-165

Nian, K. (2009). Koping Terhadap Stress pada Mahasiswa Luar Jawa Yang Mengalami. 77-80.

Sanjaya, A. (2013). Hambatan Komunikasi Antar Budaya, Antar Staf Marketing, Dengan Penghuni Berkewarganegaraan Australia dan Korea di Apartemen X Surabaya. 11-12.

Simanjuntak, R.D., (2016), Pelayanan Kesehatandalam Pendekatan Komunikasi Antar Budaya (Studi Fenomenologi Pelayanan Kesehatan Dokter Kepada Pasien Di RSUP H. Adam Malik Medan), Jurnal Simbolika: Research and Learning in Comunication Study, 2 (2): 156-166 